\title{
Transnational law - a new system of law?
}

PhD. student Alexandru BOSTAN ${ }^{1}$

\begin{abstract}
The paper presents the emergence and evolution of the concept of transnational law, from the Philip Jessup's 1956 novation to the latest approaches, mainly from the western legal scholarship. In the legal writings from Romania or Republic of Moldova, the phenomenon of transnational law remains unexplored or, at best, mentioned incidental as a synonym of a modern "lex mercatoria". Likewise, in Russian scholarship, research on transnational law bears a strong private imprint and ubiquitous reluctance may be noted. This article aims to discuss, from the perspective of legal pluralism, the loss of the state monopoly in law making, the pluralization of sources of legitimacy for transnational actors, and the reconsideration of the scope of the law, by de-territorializing it. Transnational law is seen thus not just a private regime, but as a system of normative law that transcends international or national law, acts in a distinct social space and addresses specific actors, not only private, but also public or hybrid. In Romanian legal knowledge this approach is missing.
\end{abstract}

Keywords: transnational law, transnational governance, legal pluralism, transnational legal pluralism, lex mercatoria.

\section{JEL Classification: K33}

DOI: $10.24818 / \mathrm{TBJ} / 2021 / 11 / \mathrm{SP} / 05$

\section{Introduction}

The legal field has changed substantially in recent decades, with the "permeability of borders" 2 generated by globalization, affecting the nature and role of the state. More and more authors assert that "the state is no longer the sole arbiter of what happens inside its borders" 3 , once on the global stage new legal actors with cross-boundary impact appear. This leads to the current debate on the effects of globalization in law.

Although globalization is usually disaggregated into three categories: economic, cultural and political ${ }^{4}$, no matter what form modern globalization takes, including in law, it is always a process that breaks old forms and introduces new content. In regard to law, Stephan W. Schill noted that "globalization leads to the

1 Alexandru Bostan - PhD student, lecturer, Free International University of Moldova (ULIM), Republic of Moldova, abostan@ulim.md.

${ }^{2}$ Bolintineanu, A., A. Năstase, and B. Aurescu. Drept internațional contemporan [Contemporary international law], ed. 2. București: ALL Beck, 2000, p. 5.

3 Bevir, Mark. Governance: A very short introduction. Oxford: Oxford University Press, 2012, p. 96.

${ }^{4}$ Sperling, Valerie. Altered States: The Globalization of Accountability. Cambridge: Cambridge University Press, 2009, p. 5. 
dissolution of the most fundamental classifications used to structure and define fields of law or even entire legal orders, namely the dichotomies of national and international law, on the one hand, and public and private law, on the other" ${ }^{5}$ and this is exactly the case of transnational law approach.

International law may have greater reach than border-bounded national law, "but it is rather rigid and applies [mainly] to states, and not to transnational actors" 6 so that in a globalized modern society there remain legally unregulated social relations.

In the Romanian doctrine it was also mentioned twenty years ago that "globalization is explained first of all by an unprecedented increase of interdependencies within the international society, due to the decreasing capacity of states and governments to find the necessary solutions to the problems they face" 7 , but, unfortunately, in Romanian legal science the attitude towards transnational law as a complex legal phenomenon of denationalization of law is almost missing. Thus, with small exceptions ${ }^{8}$, most Romanian authors treat transnational law exclusively from a private law perspective, as a synonym of lex mercatoria, some even stating "the concept of transnational law is not convenient to use, if not even unusable" .

To meet the challenges of a globalized law, the concept of transnational law has been revitalized in modern legal doctrine. Researchers in the field of international law or international relations increasingly use the term "transnational law", but there is no unanimity of opinion on this concept's definition or content.

In this contribution, we will speak about the emergence and evolution of this concept, about its essential elements, and we will highlight the most recent and comprehensive approach to transnational law from a pluralistic perspective, as a new legal system, above the classical public-private and international-national dichotomies, dealing with the issues brought by globalization.

\section{Contextual landmarks of the emergence of the term "transnational law"}

In a broad sense, the term "transnational" refers to "all those events, activities and processes that transcend conventional political and jurisdictional boundaries" 10 . The few definitions in the explanatory dictionaries of the Romanian language clarify the transnational adjective just as "something that transcends

${ }^{5}$ Schill, Stephan W. "Transnational legal approaches to administrative law: conceptualizing public contracts in globalization." Rivista trimestrale di diritto pubblico 1 (2014), p. 7.

${ }^{6}$ Warning, Michael J. Transnational Public Governance. Palgrave Macmillan UK, 2009, p. 45.

${ }^{7}$ Bolintineanu, A., A. Năstase, and B. Aurescu. Drept internaţional, p. 3.

${ }^{8}$ See: Calotă, Adela Teodorescu. "Concepte de drept contemporan (I): globalizare, transnaţionalism juridic, europenizare, pluralism juridic." ["Concepts of contemporary law (I): globalization, legal transnationalism, Europeanization, legal pluralism"] Revista de Stiinte Juridice 34, no. 1 (2019), pp. 159-176.

9 Constantin, Valentin. Drept internațional [International law]. București: Universul Juridic, 2010, p. 79.

${ }^{10}$ Siliquini-Cinelli, Luca. "Legal Positivism in a Global and Transnational Age: Introduction." In Legal Positivism in a Global and Transnational Age. Springer, 2019, p. 16. 
national borders" 11 , although, in our opinion, this wording is incomplete, because it can be easily misunderstood to "supranational" or even "international".

The term "transnational law" is inextricably linked to the name of Philip C. Jessup, an American international law scholar, diplomat and later judge in the first composition of the International Court of Justice, who first introduced the concept of "transnational law" in 1956 during his lectures and in form of a published work a year later. Although Jessup himself confess the term was not his original creation and refers in the footnotes of his eminent volume to some scholars who have used it occasionally before, and in a retrospective published after 17 years Jessup regrets ${ }^{12}$ he had forgotten to mention others, he was the first to apply the term "transnational" to law, "shifting attention from international law, as governing relations between states, to transnational law, as governing transnational activities"13.

Philip C. Jessup described transnational law "to include all law which regulates actions or events that transcend national frontiers. Both public and private international law are included, as are other rules which do not wholly fit into such standard categories" ${ }^{\prime 14}$.

Due to this third element ("other rules"), a first revolutionary aspect of Jessup's theory was to challenge the exclusivity and uniqueness of state jurisdiction over a given territory, as opposed to concentrating exclusive international law on the state, given that at the concept of "law" was, at the time Jessup delivered his concept, closely linked to the concept of "state", the only accepted source of legal norms being national sovereignty, thus postulated by postWestphalian legal positivism.

Legal positivists and theorists of national legal systems treat the state law as a fact ${ }^{15}$, a given, conceiving law in terms of "systems of normative ordering that have impermeable territorial and intellectual boundaries" ${ }^{16}$. Some theorists, such as Hans Kelsen, even went so far as to reduce the state to the legal system, proclaiming "the identity of the state and law" ${ }^{\prime 17}$. Nowadays, Giacinto della Cananea warns us that positivism and the nationalist paradigm inevitably face problems when confronting the contemporary realities of public law ${ }^{18}$, which was always much more "statist" than private law.

${ }^{11}$ See: https://dexonline.ro/definitie/transnational, consulted on 1.07.2021.

12 Jessup, Philip C. "The Present State of Transnational Law." In The Present State of International Law and Other Essays. Springer, Dordrecht, 1973, p. 339.

${ }^{13}$ Shaffer, Gregory, and Carlos Coye. "From International Law to Jessup's Transnational Law, from Transnational Law to Transnational Legal Orders." In The Many Lives of Transnational Law. Cambridge: Cambridge University Press, 2020, p. 126.

${ }^{14}$ Jessup, Philip C. Transnational Law. New Haven: Yale University Press, 1956, p. 2.

15 Glenn, H. Patrick. "Transnational Common Laws." Fordham International Law Journal 29, no. 3 (2005), p. 458.

16 Kleinhans, Martha-Marie, and Roderick A. Macdonald. "What is a critical legal pluralism?" Canadian Journal of Law and Society 12, no. 2 (1997), p. 29.

17 See for details: Somek, Alexander. "Stateless Law: Kelsen's Conception and its Limits". Oxford Journal of Legal Studies 26, no. 4 (2006), p. 753.

18 della Cananea, Giacinto. "Transnational public law in Europe." In Transnational Law - Rethinking European Law and Legal Thinking. Cambridge University Press. 2014, p. 343. 
As Michael J. Warning summarizes it, "because of its state-centeredness the positivist approach is insufficient for gaining a clear picture of legal interactions in the age of globalization" 19 or, in the words of a political science professor, "although the modern polity was built on the idea of the modern state and a system of statebased accountability, this notion has become outdated in the era of global institutions and their growing jurisdiction" 20 .

These days, thanks to globalization, the thesis that the state is no longer the monopolist of legal regulations is gathering recognition, various international organizations and private or hybrid actors imposing themselves through soft-law. However, in the middle of the XX siècle Jessup's theory was nothing but visionary.

Another innovation of Philip Jessup's work was the distancing from strict dichotomous division into international and national law.

The vision proposed by Jessup was supported by his American contemporaries. For example, Frederick Mann, one of the most influential legal scholars of his time, mentioned shortly after the "transnational law" term was coined, that 'the interconnection between the various branches of 'transnational law' is, in fact, greater than most lawyers are at present inclined to recognise and that some of our traditional distinctions are arbitrary and fortuitous" ${ }^{21}$. In the same manner, yet unable to conceive a law without a state, C.G. Fenwick noted soon after "the term 'international law' is to be reserved for the field of relations in which states act on the basis of treaties or customs, and a new term 'transnational law' [is] created to describe the wide variety of economic, social, and moral pressures that actually do lead nations to act without the legal obligation to do so"22.

International law has nowadays extended far beyond inter-state relations ${ }^{23}$, as it was then understood, as "a system of legal norms governing inter-state relations, for the purpose of ensuring peace and cooperation" 24 or as "primarily regulating relations between sovereign states" 25 . At present, the state is no longer the exclusive subject of international law, and international law does not exclusively regulate relations between states, but the number of subjects of public international law remains limited, or "international law traditionally recognizes only a small number of entities capable of possessing international rights or duties and of bringing international claims" 26 .

\footnotetext{
${ }^{19}$ Warning, M. J. Transnational Public Governance, p. 54.

${ }^{20}$ Sperling, V. Altered States, p. 16.

${ }^{21}$ Mann, F.A. "Transnational Law by Philip C. Jessup." The Modern Law Review 20, no. 6 (1957), p. 679.

${ }^{22}$ Fenwick, C. G. "Transnational Law. By Philip C. Jessup. New Haven: Yale University Press, 1956. p. 113. \$3.00.” American Journal of International Law 51, no. 2 (1957), pp. 444-445.

${ }^{23}$ Shaffer, G., and Carlos C. "From International Law", p. 140.

${ }^{24}$ Lukashuk, Igor Ivanovich. International law. General part: Textbook for students of law faculties and universities. Moscow: Beck, 2001, p. 9.

${ }^{25}$ Tunkin, Grigorij Ivanovich. International law theory. Moscow: Zertsalo, 2000, p. 213.

${ }^{26}$ Fahey, Elaine. "Introduction: Framing the Actors of Post-National Rule-Making." In The Actors of Postnational Rule-Making: Contemporary Challenges of European and International Law, 2015, p. 8 .
} 
Jessup envisioned transnational law will regulate the legal relations between states and supra-state, sub-state and non-state actors involved in transboundary social relations and economic transactions ${ }^{27}$, considering the term "international law" to be misleading, inappropriate and inadequate ${ }^{28}$.

Speaking on the differences between international al transnational law, Brian Z. Tamanaha outlines that Jessup's proposal did more than move from a narrower to a more comprehensive framework, because "it involves a qualitative shift from a specific juristic tradition to all regulatory activities that transcend national boundaries - an immense space with an extraordinary number and variety of arrangements" 29 .

Another dichotomy contested by Jessup was the public-private division, postulated centuries ago by the Roman jurist Ulpian, Jessup being the first to conceive the participation of private actors in cross-border regulation.

We can witness the proliferation of private actors in international law also, where non-state actors have been generally defined as including all actors who are neither states nor international organizations, i.e. "NGOs, firms and transnational networks, as well as scientific and other expert bodies" ${ }^{30}$.

The number of international organizations is growing exponentially - today we have over 73,000 international organizations (including non-governmental) ${ }^{31}$, while at the time Jessup delivered his concept only 132 intergovernmental organizations and 985 international NGOs were registered ${ }^{32}$.

As new branches of law emerge, becomes impossible to attribute them in the classical division. Many of these, such as sports law, internet law or communications law, are seen as inherent of transnational law because these legal orders cannot be incorporated into municipal or international law.

We have to acknowledge pursuits in transnational law have strong roots in Western legal culture, mainly in the United States. Although today the number of studies in the field of transnational law is considerably increasing, the start of this concept has not been easy.

In the same temporal context Jessup proposed his concept, in Soviet legal doctrine, in most cases, transnational law was approached at most in the context of transnational corporations and viewed only alongside private international law, the trepidation of Soviet authors probably stemmed from the fact that the US were the main source of transnational corporation expansion or, after the World War II "the

${ }^{27}$ Cutler, Claire. "Legal Pluralism as the 'Common Sense' of Transnational Capitalism." Oñati SocioLegal Series 3, no. 4 (2013), p. 723.

28 Jessup, Ph. C. Transnational Law, p. 1.

${ }^{29}$ Tamanaha, Brian Z. A Realistic Theory of Law. Cambridge: Cambridge University Press, 2017, p. 191.

${ }^{30}$ Green, Jessica F. "Transnational delegation in global environmental governance: When do non-state actors govern?" Regulation \& Governance 12, no. 2 (2018), p. 264.

${ }^{31} \mathrm{See}$ : https://uia.org/yearbook (The Yearbook of International Organizations), consulted on 1.07.2021.

${ }^{32}$ Shaffer, G., and Carlos C. "From International Law", p. 145. 
most prominent transnational organizations were U.S. Government agencies and U.S.-based 'multinational' corporations" 33 .

Even later, Soviet researchers were at least reluctant to accept Jessup's approach, and often mocking in their statements. For example, in 1983, in the conclusions of a doctoral thesis, the author deduced that "in bourgeois legal literature, 'transnational law' is artificially constructed" 34 .

To be fair, we must say today there are Russian authors who not only acknowledge the existence of transnational law, but go even further and state that "perhaps transnational law is not a 'division' or a related branch of international law, but only a temporary part of it, for a certain stage of development of society, economy, politics and law, and it is quite probable that transnationalization as a phenomenon will be seen later from the point of view of the intermediate period, the so-called 'neo-internationalization""35.

In a contemporary review (1957) of Jessup's work, James N. Hyde asserted "transnational law is not likely to become a term of art for a new body of law"36 and indeed, for several decades, this concept has been ignored by scholars, with international relations researchers being the first to consider the concept of "international" too narrow to describe the complexity of a globalized world ${ }^{37}$, but "in the wake of the globalization discourse dominating the 1990s and the first decade of the new millennium, the concept of transnational law gained new prominence" ${ }^{38}$ for lawyers so that "several decades after Jessup's original contribution, transnationalism became the primary orientation toward international law in American law schools" 39 and from there it spread to the European continent.

\section{Transnational (post-)modern law}

One of the many consequences of focusing on the state in the modern era has been the development of a specific form of modern international law, which evolved in parallel with the development of modern nation-states. ${ }^{40}$ Today, however,

${ }^{33}$ Huntington, Samuel P. "Transnational Organizations in World Politics." World Politics: A Quarterly Journal of International Relations 25, no. 3 (1973), p. 347.

${ }^{34}$ Osminin B.I. Transnational corporations and international law]. PhD diss., Moscow, MGU 1983 quoted in Maleev, Yurij Nikolaevich. "Transnational law: to be or not to be." International law 41, no. 1 (2010), p. 7.

${ }^{35}$ Maleev, Yu. N. "Transnational law", p. 18.

${ }^{36}$ Hyde, James N. “Transnational law.” The Yale Law Journal 66 (1957), p. 813.

${ }^{37}$ Liste, Philip. "Transnational Law". Last modified February 27, 2019. http://oxfordbibliographies online.com/view/document/obo-9780199743292/obo-9780199743292-0251.xml.

${ }^{38}$ Regulatory Hybridization in the Transnational Sphere. Leiden: Brill, 2013, 306 p. ISBN 978-90-0423392-8, p. 2.

${ }^{39}$ Mann, Itamar. "Dialectic of Transnationalism: Unauthorized Migration and Human Rights, 19932013." Harvard International Law Journal 54, no. 2 (2013), p. 322.

${ }^{40}$ Kjaer, Poul F. "The metamorphosis of the functional synthesis: a continental European perspective on governance, law, and the political in the transnational space." Wisconsin Law Review 2010, no. 2 (2010), p. 498. 
from a post-modern perspective, it is progressively stated ${ }^{41}$ that contemporary law (including international law) tends to be created steadily more by private or hybrid actors, rather than only by public actors. For example, the governing body of the internet, ICANN, with participation by public and private stakeholders, has been structured to avoid governance under a multilateral treaty ${ }^{42}$. In a doctrinal discussion, it was mentioned ${ }^{43}$ that for most states in the world it is impossible not to follow, for example, ISO standards. And the examples can go on ${ }^{44}$. As Kaarlo Tuori puts it, "state law loses its capacity to respond to regulatory needs when society undergoes denationalisation and when, as a consequence, the social space to be regulated is no longer identical with the political space of the state" ${ }^{45}$. However, the central problem observed by Elaine FAHEY is that "many of the most significant actors engaging in rule-making in contemporary times are not technically 'actors' in strict legal terms",46 of the classical legal doctrines.

The sovereignty of the nation-state satisfied the need for regulation in an era law was applying mostly locally, but in a globalized, post-modern world, this paradigm has undergone essential changes. Peer Zumbansen sees erosion and the transformation of state sovereignty due to the growing interdependence between states $^{47}$.

In a doctrinal opinion, two fundamental causes of the receding prominence of sovereignty in the postmodern era were mentioned: (1) the rise of supranational law and (2) the growing recognition of what is called "soft law" 48 , both elements contributing to the development of transnational law.

More and more authors recognize that "we live in a post-sovereign world" 49 , some drawing attention that "in this partially post-sovereignty, partially postnational world, we are witnessing novel governing arrangements" obviously requires a change of perspective from state-centered to a more "cosmopolitan" law.

${ }^{41}$ Avbelj, Matej. "Transnational law between modernity and post-modernity." Transnational Legal Theory 7, no. 3 (2016), p. 424.

${ }^{42}$ Tamanaha, B. Z. A Realistic Theory of Law, p. 192.

${ }^{43}$ Avbelj, Matej. "The concept and conceptions of transnational and global law." WZB Berlin Social Science Centre Discussion Paper SP IV 801 (2016), p. 45.

${ }^{44}$ Without claims of completeness, in the legal literature they are often mentioned as examples: World Bank, WMF, OECD, ICAO, UNCITRAL, NAFTA, WTO, BCBS, ISO, ICANN, even, in a sense, the Catholic Church; and more.

${ }^{45}$ Tuori, Kaarlo. "Transnational law: on legal hybrids and legal perspectivism." In Transnational Law: Rethinking European Law and Legal Thinking. Cambridge University Press, 2014, p. 18.

${ }^{46}$ Fahey, E. "Introduction: Framing the Actors", p. 1.

47 Zumbansen, Peer. "Comparative, global and transnational constitutionalism: The emergence of a transnational legal-pluralist order." Global Constitutionalism 1, no. 1 (2012), p. 33.

48 Tai, Eric Tjong Tjin. "Global law for private law." Tilburg Law Review 17, no. 2 (2012), p. 201.

${ }^{49}$ See e.g. Kratochwil, Friedrich. "Leaving Sovereignty Behind? An Inquiry into the Politics of Postmodernity." Legality and Legitimacy in Global Affairs, Oxford: Oxford University Press, 2012, p. 127.

50 Aleinikoff, T Alexander. "Transnational Spaces: Norms and Legitimacy". The Yale Journal of International Law 33, no. 6 (2008), p. 490. 
The same is true for case law. For example, the ICTY concluded even international law has gone beyond its state-centered boundaries. Thus, in the case of Dusko Tadic, the ICTY stipulated in an Appeals Chamber decision of 2 October 1995 that "state-sovereignty-oriented approach has been gradually supplanted by a human-being-oriented approach" 51 . This is one of the examples confirming the breakage of the intrinsic link between law and the state, which we will refer to in detail in $\S 4.1$.

Today, a growing number of scholars agree that at the stage of post-modern development both international law and domestic law have proved to be ill-suited to regulate non-state cross-border relations and, as a remedy, propose to analyze transnational law as a method, phenomenon, legal order or legal system.

The concept proposed by Jessup has often been criticized for its ambiguity. Matej Avbelj denounced Jessup's definition for being "over-inclusive" stating such a broad concept can lose any distinctive character ${ }^{52}$.

With the revival of the attentiveness of the concept, at the beginning of the 1990 s, the vagueness of the original definition led several researchers to propose their own conceptual interpretations of transnational law or contributions to transnational legal theory.

Given the abundance of definitions of transnational law, we will bring some examples below in order to relate to this concept as comprehensively as possible.

To begin with, simplifying to a feasible extent, we can look at transnational law as "any law that has cross-boundary effects" 53 or "an institutional framework for cross-border interaction beyond the nation-state" 54 . In this regard, other authors consider global law as synonymous with transnational law, but there are also scholars ${ }^{56}$ that see EU law as an epitome of transnational law and a whole branch of scholarship equals transnational to supranational and to EU law.

Some prominent international law scholars mentioned that "transnational law" is assigned to "the whole complex of rules, international and quasiinternational, municipal and quasi-municipal, which govern transactions, whether governmental or private, which transcend political or jurisdictional frontiers ${ }^{, 57}$, this definition being a bit more elaborate than Jessup's.

For British scholar Roger Cotterrell, the term transnational law refers to "extensions of jurisdiction across nation-state boundaries, so that people, corporations, public or private agencies, and organizations are addressed or directly affected by regulation originating outside the territorial jurisdiction of the nation-state in which they are situated or interpreted or validated by authorities external to it". ${ }^{58}$

\footnotetext{
${ }^{51}$ Prosecutor v. Tadic, Case No. IT-94-1-AR72, Decision on Defence Motion for Interlocutory Appeal on Jurisdiction (Oct. 2, 1995).

${ }^{52}$ Avbelj, M. "Transnational law", p. 416.

${ }^{53}$ Avbelj, M. "The concept", p. 11.

54 The Encyclopedia of Global Studies. Vol. 4. SAGE Publications, 2012, p. 1035.

55 See: Tai, Eric Tjong Tjin. "Global law for private law." Tilburg Law Review 17, no. 2 (2012): 200-205.

56 Tuori, K. "Transnational law", p. 26.

${ }^{57}$ Manual of Public International Law, ed. Max Sorensen. London: Palgrave Macmillan, 1968, p. 52.

${ }^{58}$ Cotterrell, Roger. "What is transnational law?" Law \& Social Inquiry 37, no. 2 (2012), p. 501.
} 
Addressing in a much narrower sense than Jessup, Anne-Marie Slaughter Burley noted back in 1993 - "I define transnational law to include all municipal law and a subset of intergovernmental agreements that directly regulate transnational activity between individuals and between individuals and state governments" ${ }^{\prime 59}$, further mentioning that, despite the evolution of this field of law, the definition remains one without a solid theory, with an amalgam of scattered doctrines and visions. We shall note the author proposes a "private" approach to transnational law, in which individuals participate directly.

Other authors, like Julie Dickson, refer to transnational law in an extensive manner, "as 'umbrella' term encompassing the character and theoretical understanding of the several forms of non-state law, i.e. intra-, inter-, supra- and trans-national law" ${ }^{60}$.

From a learning perspective, transnational law was seen as "the study of legal phenomena, including lawmaking processes, rules, and legal institutions, that affect or have the power to affect behaviors beyond a single state border" ${ }^{\prime \prime}$.

As we have witnessed, these descriptive definitions do not clarify the essence and the nature of the concept.

Sometimes proponents of the concept of transnational law, trying to prove its existence as a legal phenomenon, consider it a method of law. Therefore, in a 2012 paper $^{62}$, Peer Zumbansen describes transnational law as an illustration of law's attempt to reposition oneself in relation to the realities of a globalizing world and proposes to view transnational law as a methodological approach and less as a distinctly demarcated legal field. In a concurrent encyclopedic treatise, the same author notes "on the one hand, TL emerges as a series of contemplations about the form of legal regulation with regard to border-crossing transactions and fact patterns transgressing jurisdictional boundaries that involve a mixture of public and private actors and norms [...] on the other hand, transnational law continues to evolve as a thought experiment in legal methodology and legal theory". ${ }^{63}$

We can find this approach to transnational law as a method also in Russian scholars' works. Thus, Yurij Nikolaevich Maleev, notes "we can speak of transnational law not as a 'normative body', but as a legal method: there are no rules of transnational law, there is no transnational law in itself, but there is a certain method of solving the problem of order enforcement, [...] in other words, a method of regulation that is applied 'temporarily' until states apply methods of legal regulation using the norms of domestic or international law" ${ }^{64}$.

\footnotetext{
${ }^{59}$ Burley, Anne-Marie Slaughter. "International law and international relations theory: a dual agenda." The American Journal of International Law 87 (1993), p. 230.

${ }^{60}$ Dickson, Julie. "Who's afraid of transnational legal theory? Dangers and desiderata." Transnational Legal Theory 6, no. 3-4 (2015), p. 566.

${ }^{61}$ Menkel-Meadow, Carrie. "Why and how to study transnational law." UC Irvine Law Review 1, no. 1 (2011), p. 104.

${ }^{62}$ Zumbansen, Peer. "Defining the space of transnational law: Legal theory, global governance, and legal pluralism." Transnational Law and Contemporary Problems 21 (2012), p. 307.

${ }^{63}$ Zumbansen, Peer. "Transnational law, evolving." In Elgar Encyclopedia of Comparative Law, Second Edition. Edward Elgar Publishing, 2012, p. 898.

${ }^{64}$ Maleev, Yu. N. "Transnational law”, p. 22.
} 
According to Vladimir Mihajlovich Shumilov, who treats from a private law perspective, transnational law can be seen in two ways: on the one hand, as a normative unit; on the other hand - as a method of normative regulation ${ }^{65}$. Shumilov argues transnational law is a conventional designation of a certain institutional and legal phenomenon in the international system, the essence of which is that private persons (mainly multinational enterprises, banks, stock exchanges) from different states create their own bilaterally and multilaterally interaction rules. Such rules appear in those aspects that are not regulated by either domestic or international law (i.e., where there are legal loopholes) or are regulated in both systems in a generally permitted manner - based on the principle "all that is not forbidden is allowed" ${ }^{\prime 6}$.

Speaking on the revival of transnational doctrine in the early 1990s, one should mention American scholar Harold Hongju Koh who proposed back in 1994 the concept of transnational legal process, which represents "the theory and practice of how public and private actors - nation-states, international organizations, multinational enterprises, non-governmental organizations and private individuals - interact in a variety of public and private, domestic and international fora to create, interpret, apply and ultimately internalize the rules of international law" ${ }^{67}$.

For Koh, transnational law is a dimension of a much broader phenomenon of transnational legality and pluralistic governance in which the regulatory activities of a multitude of actors overshadow international law. ${ }^{68}$ Koh argued that the courts, as well as other public and private agencies, are in a constant cross-border dialogue and through this dialogue, called the transnational legal process, these various institutions interpret international law and influence each other to "internalize" and further enforce international law. ${ }^{69}$

With the emergence and development of the modern theory of lex mercatoria (whose key point resides in its creation by institutions outside the state), an attempt was made to narrow the term transnational law to this concept.

Even today in the Romanian legal literature it is mentioned "a-national law is also called transnational and is created by international trade operators or international organizations; [...] lex-mercatoria, the practices of international trade and the general principles of international trade are part of a-national law"70. Distinguished professor Raluca Miga-Beșteliu sees transnational law just as a body of law that governs contractual legal relations between states and subjects of domestic law from other states ${ }^{71}$.

\footnotetext{
${ }^{65}$ Shumilov, Vladimir Mihajlovich. “About 'Global Law' as an emerging legal supersystem.” Moscow Journal of International Law 4 (2015): 4-17, p. 12.

${ }^{66}$ Idem, p. 11.

${ }^{67}$ Koh, Harold Hongju. “Trasnational Legal Process.” Nebraska Law Review 75 (1996), p. 183-184.

${ }^{68}$ Cutler, C. "Legal Pluralism", p. 724.

${ }^{69}$ Mann, I. "Dialectic of Transnationalism", p. 322.

${ }^{70}$ Ungureanu, Carmen Tamara. Dreptul comerțului internațional: contracte de comerț internațional [International trade law: international trade contracts]. București: Hamangiu, 2014, p. 201.

71 Miga-Besteliu, Raluca. Drept internațional public [Public international law]. Vol. I. Ed. 3. București: C.H. Beck, 2014, p. 3.
} 
Likewise, in most Russian doctrinal sources, transnational law is treated only in this narrow sense, as a new field of private international law. For example, Boris Ivanovich Nefedov suggests transnational norms are often referred to by the term "lex mercatoria", outlining, in the spirit of Russian scholarship, that non-state regulation of public relations, i.e. the law created by participants in legal relations, is the main component of transnational law. ${ }^{72}$

Another Russian author, Mihail Rolandovich Berandze, concludes in his $\mathrm{Ph} . D$. dissertation "transnational law exists, but exclusively in the field of international trade relations and should not be called other than lex mercatoria" "73. He considers that, despite the existence of a separate legal system in the form of international law and the branch of domestic law in the form of private international law, which governs a wide range of public relations, transnational corporations and other legal entities have been forced to create the legal phenomenon of lex mercatoria, which made it possible to protect their interests in the field of external economic relations, without involving any other legal regulatory body from the field of private international law. ${ }^{74}$

However, we consider the approach to transnational law as equal to modern lex mercatoria implies a much narrower definition of transnational law than the original one suggested by Jessup.

It was noted ${ }^{75}$ that while a major prong of transnational legal theorizing focuses on private law and private law-making, public law components of transnational law remain central and critically important.

Indeed, the general shift in perspective and the trend towards transnationalisation is not limited to private regimes. A similar process of transformation relates to the area of public law where legal operations are also increasingly no longer bound to the classical paradigm of the nation-state and its organs; instead, they become more and more transnational, therewith also questioning our traditional understanding of the law. ${ }^{76}$ There is a transnationalization of some established areas of public law, such as environmental law, criminal law (transnational crimes), or even the emergency of new theories on transnational administrative law or transnational constitutionalism.

When asked whether transnational law is primarily a procedural, coordinating law, linking state and other legal regimes to serve transnational networks, or whether it represents a new substantive law regime existing alongside state law $^{77}$, in recent times, scholars frequently argue transnational law to be its own,

\footnotetext{
${ }^{72}$ Nefedov, Boris Ivanovich. Catechism of a postgraduate student of the Department of International Law. Moscow: MGIMO, 2018, pp. 148-149.

${ }^{73}$ Berandze, Mihail Rolandovich. "The concept of transnational law in international law." PhD diss., Diplomatic Academy of the Ministry of Foreign Affairs of the Russian Federation, 2010, p. 4.

${ }^{74}$ Idem, p. 9.

${ }^{75}$ Shaffer, G., and Carlos C. "From International Law”, p. 129.

${ }^{76}$ Augsberg, Ino. "Observing (the) Law: The 'Epistemological Turn' in Public Law and the Evolution of Global Administrative Law.” In Regulatory Hybridization in the Transnational Sphere. Brill Nijhoff, 2013, p. 12.

${ }^{77}$ Cotterrell, R. "What is", p. 501.
} 
autonomous body of law, which "has been triggered by the rise of new actual and putative authorities in and beyond the state" 78 .

Although viewed from the same narrow perspective of private law, some Russian authors also speak of "the formation of transnational law as the 'third' component of the global legal system, which governs relations not governed by either domestic or international law"79 or "the formation of a completely new universal regulator of normative relations, which does not fall under the jurisdiction of either national or international law, which is formed as an autonomous legal system and is called transnational law" $" 80$.

Gralf-Peter Calliess, treating the issue from the same angle, considers that transnational law should be seen as "a third-level autonomous legal system beyond municipal and public international law, created and developed by the law-making forces of an emerging global civil society, founded on general principles of law as well as societal usages, administered by private dispute resolution service providers, and codified (if at all) by private norm formulating agencies" $"$.

The above-mentioned global civil society includes, in the opinion of Western scholars, not only non-governmental organizations but also "corporations, professional societies, business associations, advocacy groups and many other types of collectivities that are not considered to be governments" $" 82$. Increasingly frequent references to civil society are influenced by "the ability of individuals at the micro level to interact with and within their macro collectivities" $" 83$ and result in more and more scholars shifting their emphasis from the state to society. From this societal perspective, some jurists opine ${ }^{84}$ that transnational law could be conceived as a "bottom-up" law (developed through social interaction) rather than "top-down" (legislated).

The fact that authors today apply the term "transnational law" to autonomous normative systems established by civil society actors allows us to understand transnational law as an autonomous legal order, separate from national or international legal orders. ${ }^{85}$

Kaarlo Tuori contends that transnational law displays feature of a legal system because, in addition to a distinctive normative order, it possesses court-like bodies for settling disputes or sanctioning ${ }^{86}$.

\footnotetext{
${ }^{78}$ Avbelj, M. "Transnational law", p. 415.

${ }^{79}$ Maleev, Yu. N. "Transnational law", p. 7

${ }^{80}$ Kudelka, Oleg Sergeevich. "On the formation of transnational law." Student Science Issues 4, no. 32 (2019)], p. 104.

${ }^{81}$ Calliess, Gralf-Peter. "Reflexive transnational law: The privatisation of civil law and the civilisation of private law." Zeitschrift für Rechtssoziologie 23 (2002), p. 188.

${ }^{82}$ Rosenau, James N. "Governance in a new Global Order" In The global transformations reader: an introduction to the globalization debate, $2^{\text {nd }}$ edition. Cambridge: Polity Press, 2003, p. 224.

${ }^{83}$ Koehn, Peter H., and James N. Rosenau. "Transnational competence in an emergent epoch." International Studies Perspectives 3, no. 2 (2002), p. 106.

${ }^{84}$ Cotterrell, R. "What is", p. 510.

${ }^{85}$ Warning, M. J. Transnational Public Governance, p. 53.

86 Tuori, K. "Transnational law", p. 26.
} 
Another adherent of the concept of the autonomous system of transnational law, Matej Avbelj, proposes to make a distinction between the narrow and the broad meaning of transnational law. Thus, transnational law lato sensu encompasses any law whose effects extend beyond the state, while transnational law stricto sensu refers only to the body of transnational law that does not originate, directly or indirectly, from state bodies. Transnational law stricto sensu is thus transnational law without a state. ${ }^{87} \mathrm{He}$ draws a map, which in his opinion, reflects the structure of transnational law, composed of three parts. Thus, transnational law lato sensu can be: (1) Public (International law, Supranational law, Private international law, Transnational human rights regimes), (2) Administrative (Public, Hybrid, Private) and (3) Private (New lex mercatoria, Transnational corporate law) ${ }^{88}$.

The acknowledged approach of transnational law being an autonomous system of the global legal order is, of course, strongly contested by traditional legal theorists, being accepted only as a quasi-legal phenomenon of soft law.

\section{The concept of transnational legal pluralism}

As we observed in the previous paragraph and as others have noted, "one of the most influential narratives of transnational law is one that equates transnational law with the "New Law Merchant" 89 , but recently, in the late 2000s, in studies of some Western researchers an orientation toward a broader engagement that takes into account both the law and its politico-social environment has become stronger ${ }^{90}$.

The new wave of legal research extends the positivist, state-centered conceptions of law and proposes new comprehensive approaches to transnational law.

In 2009, Craig Scott submitted in an emblematic article three possible theoretical perspectives to transnational law, noting that he did not intend to impose any of these as the sole interpretation of the concept proposed by Jessup "'transnational law' operates in the present analysis not as an established concept but more as a kind of fuzzy or suggestive proto-concept" ${ }^{\text {"91 }}$.

According to Scott, the concepts applied to transnational law can be classified into 1. Transnationalized Legal Traditionalism; 2. Transnationalized Legal Decisionism; 3. Transnational Socio-legal Pluralism.

Adherents of the first concept believe that any law applicable to transnational phenomena has its roots in the national or international law, so transnational law can therefore be seen as a series of special issues in the broader field of international or national law. In other words, "it is not the law but rather the regulated issues which are transnational" $" 92$.

${ }^{87}$ Avbelj, M. "Transnational law", p. 417

${ }^{88}$ Idem, pp. 417-422.

${ }^{89}$ Maurer, Andreas. "Transnational maritime law." In The Hamburg Lectures on Maritime Affairs 2011-2013. Berlin: Springer, p. 129.

${ }^{90}$ Liste, Ph. "Transnational Law".

${ }^{91}$ Scott, Craig. “'Transnational Law' as Proto-Concept: Three Conceptions”. German Law Journal 10, no. 6-7 (2009), p. 864.

${ }^{92}$ Calliess, G.-P. "Reflexive transnational law", p. 188. 
In the view of Transnationalized Legal Decisionism transnational law is understood as the resulting interpretations or applications of domestic and international law to transnational situations. ${ }^{93}$

The two concepts above, although introducing a transnational element in the field of law, remain rooted into the classical view of law as a state phenomenon.

Instead, the third conception, transnational socio-legal pluralism, considers transnational law "as being in some meaningful sense autonomous from either international or domestic law, including private international law as a cross-stitching legal discipline" 94 .

The theory of "transnational legal pluralism" goes beyond Philip Jessup's concept of transnational law and "brings together insights from legal sociology and legal theory with research on global justice, ethics, and regulatory governance to illustrate the transnational nature of law and regulation"

For a better understanding of the term "transnational legal pluralism", we shall have a brief foray into the concept of "legal pluralism", which is a central point in reconceptualizing the relationship between law and society, being qualified as "the key concept in a post-modern view of law" pluralistic insight dates from at least Montesquieu"97.

Legal pluralism refers to "a context in which multiple legal forms coexist" 98 and can be in essence defined as "the state of affairs in which a category of social relations is within the fields of operation of two or more bodies of legal norms"

Speaking of the revival of legal pluralism, Sally Engle Merry identifies two periods and mentions "classical legal pluralism", which is the analysis of the intersection of indigenous and European law (understood in the sense of European states law, not as EU law) and the "new legal pluralism", which refers to the interest of socio-legal scholars to apply the concept of legal pluralism to non-colonized societies, in particular highly industrialized ones in Europe and the USA, focusing on the relationship between the official legal system and other forms of ordering, connected but somewhat separate. ${ }^{100}$

The paradigm of the new legal pluralism, without being called so, was defined in the 1980s by John Griffiths, who postulated without appeal that "legal pluralism is the fact; legal centralism is a myth" ${ }^{101}$. Griffiths' approach consists in normative heterogeneity accompanied by the fact that social action always takes place in a context of multiple, overlapping "semi-autonomous social fields"102.

${ }^{93}$ Scott, C. “'Transnational Law' as Proto-Concept”, p. 871.

${ }^{94}$ Idem, p. 873.

${ }^{95}$ Zumbansen, P. "Defining the space", p. 311.

${ }^{96}$ de Sousa Santos, Boaventura. "Law: a map of misreading. Toward a postmodern conception of law." Journal of Law and Society 14, no. 3 (1987), p. 297.

${ }^{97}$ Kleinhans, M.-M., and Roderick A. M. "What is", p. 29.

98 Tamanaha, Brian Z. "The rule of law and legal pluralism in development." Hague Journal on the Rule of Law 3, no. 1 (2011), p. 2.

${ }^{99}$ Woodman, Gordon R. "Legal pluralism and the search for justice.” Journal of African Law 40 (1996), p. 157.

${ }^{100}$ Merry, Sally Engle. “Legal pluralism.” Law \& Society Review 22, no. 5 (1988), pp. 872-873.

${ }^{101}$ Griffiths, John. "What is legal pluralism?" The Journal of Legal Pluralism and Unofficial Law 18, no. 24 (1986), p. 4.

102 Idem, p. 38. 
As an example, were brought commercial enterprises that prefer to avoid state legal systems and can resort to (or create) alternatives, like independent commercial arbitration or a tribunal instituted by the merchants themselves that operate apart from the official legal system. ${ }^{103}$

Andreas Maurer states we must accept there are other forms of regulation besides national law and brings as an example the music and movie industry, which did not rely on the protection of their intellectual property by nation-states, but developed their own copy-protection mechanisms. Private organizations, then, he argues, are legislators in the transnational realm; lex mercatoria, lex electronica, lex contructionis or lex sportiva being only synonyms for a de-nationalization and "socialization" of law in which the differences of national law and non-state law are increasingly blurred. ${ }^{104}$

The doctrine of legal pluralism has evolved a lot, and today there are debates about "post-national pluralism" 105 , which contains a diverse range of institutions and states producing norms at the transnational level or about "global legal pluralism" 106 , seen as an intermediate field between sovereign territorialism and universalism ${ }^{107}$, which cannot be encompassed in the strict Westphalian paradigm.

Getting back, an iconic and prolific representative of the third, pluralistic conception of transnational law in Craig Scott's categorization is Peer Zumbansen.

Zumbansen's approach - labeled “transnational legal pluralism”focusing on the co-existence and competition between hard and soft, official and unofficial, public and private norms, suggests the study of law within the context of evolving theoretizations of societal ordering. ${ }^{108}$

For P. Zumbansen, "transnational legal pluralism" means something more than "transnational law" in Jessup's understanding. Zumbansen advocates the existence of a transnational legal-pluralist order, which is characterized by "forms of 'legal' regulation which increasingly encompass a variety of direct and indirect, hard and soft, public and private, domestic or global types of norms, standards, recommendations and guidelines" ${ }^{109}$.

Zumbansen's viewpoint marks the process of transition in legal theory from a state-based definition of law to a concept of legal norm-creation based on functional specialization. ${ }^{110}$

\footnotetext{
${ }^{103}$ Tamanaha, B. Z. "The rule of law", p. 12.

${ }^{104}$ Maurer, Andreas. "The Concept of Participation in the Making of Transnational Law: Legitimization and Normativity in the Transnational Sphere." In Regulatory Hybridization in the Transnational Sphere. Brill Nijhoff, 2013, p. 219.

105 Isiksel, Turkuler. "Global legal pluralism as fact and norm." Global Constitutionalism 2, no. 2 (2013), p. 163.

106 See: Merry, Sally Engle. "Global legal pluralism and the temporality of soft law." The Journal of Legal Pluralism and Unofficial Law 46, no. 1 (2014): 108-122.

107 Berman, Paul Schiff. "From Legal Pluralism to Global Legal Pluralism." In Law, Society and Community. Socio-Legal Essays in Honour of Roger Cotterrell, Routledge, 2014, p. 257.

108 Zumbansen, Peer. "Law and Legal Pluralism: Hybridity in Transnational Governance." In Regulatory Hybridization in the Transnational Sphere. Brill Nijhoff, 2013, p. 57.

109 Zumbansen, P. "Law and Legal Pluralism", p. 63.

${ }^{110}$ Garcia, Frank J. “Globalization's Law: Transnational, Global or Both?” In The Global Community Yearbook of International Law and Jurisprudence 2015. Oxford: Oxford University Press, p. 39.
} 
The importance of the approach through the prism of transnational legal pluralism consists of offering the field of maneuver to escape the internationalnational dichotomy and building a new approach to regulating social phenomena in a new conceptual space. Thanks to the pluralistic viewpoint, we no longer have to limit ourselves to the two plans, but we can extend the legal regulations outside these fields. We shall conceive the existence of law beyond the state normativity, this being a first step towards identifying institutions that operate in the transnational space.

\subsection{Implications for the state and law}

As Poul F. Kjaer sees it, "transnational law is understood as a form of interhierarchical law that to a large extent has emerged from, but that cannot be reduced to, classical state-centered international law" $" 111$ and we have to reconsider the wellestablished assumption of the territorial connection of law to an institutionalized system, generally called "state-law nexus" 112 .

In Romanian doctrine, a common way to speak about law is as the totality of the legal norms elaborated, enforced or recognized by the state ${ }^{113}$. In the same vein, prof. Dumitru Baltag, like many other legal theorists, states that by law we must understand "only the system of rules to which the state ensures its coercive force" 114 and that "the effectiveness of the law consists precisely in the fact that it expresses the will of the state" $" 115$

On the contrary, Craig Scott observes that at the current stage there is a new body of scholarship that intends "to demonstrate that law need not be conceptualized as having to have either a direct or a derivative relationship to the state or the interstate order" ${ }^{116}$. By accepting this assertion, of law not bounded by state, legal pluralism offers the possibility to embrace the concept of transnational law in its broadest form.

The advocates of transnational law argue that, while modern law has been almost exclusively associated with the state as a territorial entity, transnational law is largely a product of non-statist functional entities. ${ }^{117}$ Even though many voices are claiming the state has lost its monopoly on legal regulation, theoreticians of law continue to consider ${ }^{118}$ the link between law and state inseparable, preserving the positivist approach that if law is not adopted or enforced by the state, then it is not law.

${ }^{111}$ Kjaer, P. F. "The metamorphosis", p. 493.

112 Zumbansen, P. "Defining the space", p. 308.

113 See e.g. Voicu, Costică. Teoria generală a dreptului [General theory of law]. București: Universul Juridic, 2008, p. 46; Mazilu, Dumitru. Teoria generală a dreptului [General theory of law]. București: All Beck, 1999, p. 66.

${ }^{114}$ Baltag, Dumitru. Teoria generală a dreptului [General theory of law]. Chișinău, 2013, p. 173.

${ }^{115}$ Idem, p. 174.

${ }^{116}$ Scott, C. “"Transnational Law' as Proto-Concept”, p. 874.

117 Avbelj, M. "Transnational law", p. 424.

118 See: Baltag, Dumitru, and Ecaterina Baltaga. "Pluralismul punctelor de vedere în problema definirii dreptului în gîndirea juridică europeană." ["The pluralism of points of view in the problem of defining law in European legal thinking"] Legea şi Viaţa 287, no. 11 (2015): 4-9. 
Because of globalization, many non-territorial, functional entities have emerged with powers and competencies matching and sometimes surpassing those of states ${ }^{119}$, today transnational corporations are transformed into agencies that can substitute the state providing goods and services to citizens that were offered in the past by the state ${ }^{120}$, so that a wide range of autonomous public- and private-norm producing organizations and regimes operates in transnational space ${ }^{121}$.

Namely the attempt to provide a formalized framework for these social relations arouses interest in transnational law, some doctrinaires going so far as to define transnational law as "the law of non-state governance systems" 122 , totally excluding the state from the creation of transnational law, an opinion which we do not agree, or, as we will describe below, transnational law has a multitude of sources of regulation, including the state.

References to transnational law as the main form of manifestation of nonstate law are so frequent in Western scholarship that some authors have even undertaken to demonstrate that similar forms of non-state law existed before transnational law. Thus, through the examples given (maintaining a British Judicial Committee of the Privy Council as their highest court of appeal in some independent states, such as Singapore or New Zealand, or the coexistence of two legal systems in Scotland) Julie Dickson adequately demonstrates ${ }^{123}$ several states previously recognized and accepted the authority of extra-state judicial institutions or the coexistence of two legal orders, in contradiction with the Westphalian paradigm. Moreover, César Arjona enumerates ${ }^{124}$, in his vision, three pre-Westphalian examples of transnational law: Roman law, religious law and pre-modern private governance, illustrated by (classical) lex mercatoria and medical ethics (Hippocratic Oath).

Critics of transnational law argue that states are still the most relevant and powerful actors in a globalized world and that the consideration of non-state entities as sources of law is conceptually confusing and there should be a strong distinction between state and non-state sources.

As mentioned above, many researchers deny the existence of legal norms other than those enforced by the state. This attitude is clear-cut in the Russian scholarship, where it is mentioned, for example, "the difference between the norms of law and other social norms is made precisely on the basis of their direct connection with the state. Legal norms are created by the state or sanctioned by it. There is no such connection - there are no legal rules" $" 125$.

${ }^{119}$ Avbelj, M. "Transnational law", p. 412.

${ }^{120}$ Tourkochoriti, Ioanna. "Beyond Legal Positivism in Transnational Law." In Legal Positivism in a Global and Transnational Age. Springer, 2019, p. 271.

${ }^{121}$ Kjaer, P. F. "The metamorphosis", p. 489.

122 Backer, Larry Catá. "The Foundations of an Emerging Field". Last modified March 09, 2007. https://lcbackerblog.blogspot.com/2007/03/principles-of-transnational-law.html, consulted on 1.07.2021.

${ }^{123}$ See: Dickson, J. "Who's afraid".

124 Arjona, César, et al. "What law for transnational legal education? A cooperative view of an introductory course to transnational law and governance." Transnational Legal Theory 6, no. 2 (2015), p. 265.

${ }^{125}$ Nefedov, B. I. Catechism, p. 155. 
Some authors even consider that the role of the state is reduced to the function of reproducing a system of norms, otherwise, no other social fact would attest its existence. ${ }^{126}$

On the other hand, Brian Z. Tamanaha argues "although state law is a familiar form of law today, the territorial state with a unified, hierarchical system of law is only a few centuries old"127 and brings examples of past non-state forms of law. Some authors even claim the existence of law before the state, which explains and justifies the existence of the state, so that the state is the result, not the source of the law ${ }^{128}$, but this debate is certainly not the subject of this paper.

Although since the $17^{\text {th }}$ century, law has been seen as an expression of state power and is understood as an instrument of the state, ${ }^{129}$ in the age of globalization, "formal identification of law with the state fails to clearly illuminate law in spaces where the state is not the only or even the dominant regulatory actor" ${ }^{\prime 130}$, given that "many economic, financial, environmental, social, political and military processes that affect the lives of the population are beyond the control of nation-states"131.

Karl-Heinz Ladeur stated already in 1997 the state had lost its central hierarchical importance or "a large part of the law currently applying in international economic relations is in fact the exclusive product of private, no longer territorially attributable practice, in which law-making and implementation are mixed"132. We can observe the boundary between legal norms and other social norms, which was indispensable for the law's formal rationality, is blurring.

Larry Catá Backer claims ${ }^{133}$ that reconsidering the idea that law proceeds in specific form solely from the acts of political communities shall weaken the centrality of law and the state. In that regard, speaking about several normative creation plans, which disturbed the modernist vision of law, Matej Avbelj asserts that "our world now contains a plurality of sources of law [...]; ours is thus the era of legal poly-centricity" 134 , but this growing poly-centricity "questions the fiction of a state will expressing itself in law" 135 .

Some authors even consider that the purpose of transnational regimes is to weaken national states and reduce their sovereign power ${ }^{136}$.

\footnotetext{
${ }^{126}$ Somek, A. "Stateless Law", p. 753.

127 Tamanaha, B. Z. A Realistic Theory of Law, p. 194.

${ }^{128}$ Glenn, H. P. "Transnational Common Laws", p. 461.

${ }^{129}$ Backer, Larry Catá. "Reifying Law-Government, Law and the Rule of Law in Governance Systems." Penn State International Law Review 26 (2007), p. 523.

${ }^{130}$ Garcia, F. J. "Globalization's Law", p. 38.

${ }^{131}$ Varlamova, Natalija Vladimirovna. "Problems of institutionalization of the supranational level of the exercise of public authority." Proceedings of the Institute of State and Law of the Russian Academy of Sciences 6 (2014), p. 10.

${ }^{132}$ Ladeur, Karl-Heinz. "Towards a Legal Theory of Supranationality — The Viability of the Network Concept." European Law Journal 3, no. 1 (1997), p. 45.

133 Backer, L. C. "Reifying Law", p. 545.

${ }^{134}$ Avbelj, M. "Transnational law", p. 424.

135 Tuori, K. "Transnational law", p. 24.

${ }^{136}$ Capuzzo, Giacomo. "Legal Expertise: On Some Uses of Law in Transnational Regimes." Comparative Law Review 4, no. 2 (2013), p. 3.
} 


\subsection{Implications on space}

Law that transcends national frontiers moves beyond territorial definitions of sovereignty in public international law ${ }^{137}$ and requires a distinctive approach to the concept of space.

Although some authors consider that apart from the "traditional" structures that operate "below" the structures of modern states, the transnational layer is a third vertical layer that functions "above" the state ${ }^{138}$, the theorists of transnational legal pluralism suggest the idea of approaching the law from a transnational perspective does not merely have the empirical dimension of a trans-border activity, but it goes at the very element of conceptualizing space as demarcated by boundaries ${ }^{139}$.

In the same vein, an encyclopedic work states that "in distinction of territorially organized national and international law, [transnational law] is structured as a plurality of functionally specialized transnational law regimes, which in a pragmatic approach combine different governance mechanisms of private (norms, alternative dispute resolution, social sanctions) and public (laws, courts, enforcement) origin, where the latter are disembedded from their domestic context" $" 140$.

In a similar way, in a paper dedicated to the architecture of transnational private regulation, Fabrizio Cafaggi notes that "unlike in the traditional multilevel governance literature, where 'levels' are primarily defined on the basis of a territorial metric, here the notion of regulatory space is functional and independent from the administrative boundaries of nation-states" ${ }^{141}$. Therefore, transnational law adopts not territorial but functional criteria for differentiation from other legal systems. ${ }^{142}$

Brian Z. Tamanaha also argues that "transnational law encompasses the forms of law and regulation that exist in the space between and across polities, including aspects of state law, international law in its entirety, and other bodies of law like new lex mercatoria" 143 .

In the spirit of transnational socio-legal pluralism, Peer Zumbasen says we should "refrain from too quickly depicting the 'transnational' as a distinct regulatory space, which differs from the national and the international because of its de-territorialised scope and its hybrid, including mixed public-private, constitution. Instead, transnational law can be perceived as a particular perspective on law as part of a society, which itself cannot sufficiently be captured by reference to national or de-nationalised boundaries" ${ }^{144}$.

${ }^{137}$ Irish, Maureen. "Transnational Law and Legal Education.” Windsor Yearbook of Access to Justice 31, no. 1 (2013), p. 216.

${ }^{138}$ Kjaer, P. F. "The metamorphosis", p. 501.

139 Tourkochoriti, I. "Beyond Legal Positivism”, p. 255.

${ }^{140}$ The Encyclopedia of Global Studies, p. 1035.

${ }^{141}$ Cafaggi, Fabrizio. "The architecture of transnational private regulation." EUI Department of Law Working Papers 2011/12 (2011), p. 4.

142 Tuori, K. "Transnational law", p. 26.

${ }^{143}$ Tamanaha, B. Z. A Realistic Theory of Law, p. 180

${ }^{144}$ Zumbansen, Peer. "Transnational legal pluralism.” Transnational Legal Theory 1, no. 2 (2010), p. 168. 
In this regard, Poul F. Kjaer noted "apart from feudal structures and modern statehood, the transnational realm must be understood as a third layer of socialpattern reproduction unfolding within world society" ${ }^{145}$.

Although legal theorists continue to consider that "any legal system is deployed in a certain spatiality that extends over a territory and is limited by certain borders" ${ }^{146}$, the de-territorialized approach to space is not new, being described with the emergence of the new legal pluralism, when we were asked to look at social space in a specific way as "divided into a number of co-existing, more or less discrete compartments" $" 147$, i.e. some coexisting legal fields/domains/orders/systems, as "different legal spaces superimposed, interpenetrated and mixed"148. Moreover, some doctrinaires believe transnational law requires us to rethink not only the spatial but also the temporal dimension of law.

Bottom line, the nature of space in transnational law is less a geographical or "spatial" one, but rather an argumentative and conceptual one. ${ }^{149}$

In the light of the foregoing, we can highlight two defining methodological premises for transnational legal pluralism: (1) understanding the notion of "transnational" not as defining a territorial space across boundaries, but as a conceptual space between national and international characterizations of law and (2) inquiry into the elements that inform the distinction between law and non-law in any given regulatory context, ${ }^{150}$ without a limitation to the state.

\section{Final comments}

James Carter, president of the American Society of International Law, stated back in 2004 that "we have all become transnational" 151 . Indeed, as the UN Commission on International Law concludes in a report finalized by Martti Koskenniemi in 2006, "one aspect of globalization is the emergence of technically specialized cooperation networks with a global scope [...] - spheres of life and expert cooperation that transgress national boundaries and are difficult to regulate through traditional international law. National laws seem insufficient owing to the

${ }^{145}$ Kjaer, Poul F. "The concept of the political in the concept of transnational constitutionalism: A sociological perspective." In After Globalization: New Patterns of Conflict and their Sociological and Legal Reconstruction. Oslo: Arena, 2011, pp. 285-286.

${ }^{146}$ Negru, Boris, and Alina Negru. "Teritoriul și spațialitatea juridică a statului (II).” [“Territory and legal space of the state (II)"] Administrarea Publică 94, no. 2 (2017), p. 44.

${ }^{147}$ Roberts, Simon. "Against Legal Pluralism”. The Journal of Legal Pluralism and Unofficial Law 30, no. 42 (1998), p. 101.

148 de Sousa Santos, B. "Law: a map", p. 297.

149 Zumbansen, P. "Law and Legal Pluralism", p. 58.

${ }^{150}$ Garcia, F. J. "Globalization's Law”, p. 39.

${ }^{151}$ Carter, James H. "Transnational Law: What Is It-How Does It Differ from International Law and Comparative Law.” Penn State International Law Review 23, no. 4 (2004), p. 798. 
transnational nature of the networks while international law only inadequately takes account of their specialized objectives and needs ${ }^{\prime 152}$. Other authors ${ }^{153}$, in fact, see concerns about the fragmentation of international law as the dawn of transnational law.

As Matej Avbelj puts it, "we are talking today about transnational and global law not because they are some fancy scholarly inventions, but because they are real [...], their existence is inevitable" 154 .

We have analyzed throughout the article the potential meanings of the term transnational law and, although there is no unity of opinion on the content of the concept, we can easily observe its evolution. Since a "neologism" proposed by Jessup in 1956, the term has come a long way, in which different content and meanings have been attributed to it, today some dominant conceptions are already solidifying, with several common features.

Regardless of the preferred approach, transnational law requires a fundamental reconsideration of established legal scientific categories on which national and international law have traditionally been based, between law and state and between different law and legal authority sources.

In claiming new forms of non-state norm creation, transnational law shows us the changing role of the state in the global world, and most of the concepts described in this paper are based on the premise of the decline of national sovereignty.

As we have seen, although outside the doctrine of transnational law the central position remains that only the state can provide coercive force to the law and that there is no law outside the state, for most lawyers embracing the concept of transnational law it is clear that "competences and power structures have migrated beyond the state $[\ldots]$, the decisions are now taken somewhere else" 155 and that "the state has lost its monopoly over law-making"156.

We have noticed opinions on the role of the state of transnational law scholars differ: some consider the state is no longer an actor in transnational law, regulating only the relations of individuals, corporations and associations in civil society (those who identify transnational law with lex mercatoria), and others consider the state as a regular, unprivileged actor, along with other global/transnational civil society actors. Despite the multitude of views on the "privatization" of the regulatory process, from our point of view, transnational law is to be viewed more broadly than just a private transnational law, as a concept that encompasses public, private and hybrid regulators and addresses a wide range of actors.

The exponents of the transnational approach invite us to reflect on what

\footnotetext{
${ }^{152}$ UN International Law Commission. Fragmentation of international law: difficulties arising from the diversification and expansion of international law. 2006. Para. 481 https://legal.un.org/ilc/documentation/english/a_cn4_1682.pdf, consulted on 1.07.2021.

153 Tuori, K. "Transnational law", p. 22.

${ }^{154}$ Avbelj, M. "The concept", p. 23.

${ }^{155}$ Idem, p. 39.

${ }^{156}$ Avbelj, M. "Transnational law", p. 424.
} 
should be considered law. Whether viewed primarily as a body of substantive law or as a methodology, transnational law, implies an enlarging of law's vision field ${ }^{157}$ and touches upon the core questions of legal theory: what is law and who makes it? ${ }^{158}$

The question of what constitutes "law" is an ongoing debate among legal theorists, not just those concerned with transnational law, or, as H.L.A. Hart noted in his famous work "The Concept of Law", "few questions concerning human society have been asked with such persistence and answered by serious thinkers in so many diverse, strange, and even paradoxical ways as the question 'What is law?'“159.

Is it possible that some sources of law now exist entirely outside the realm of state authority? The modern concept of law has been profoundly affected in all its constituent elements, but especially in its statist character. Transnational law not only implies the acceptance of the creation of law outside the state, by different actors, but also offers new opportunities for what can be considered law.

A general criticism expressed against law outside the state is that such law has no democratic legitimacy ${ }^{160}$ so, despite the attractiveness of the concept of transnational law, its biggest problem is precarious legitimacy. As most researchers point out, a major issue for transnational regimes is both their legitimacy (their recognition and acceptance as established) and their authority (their ability to induce deference from others). The legitimacy and authority of national/international law are based on the democratic foundations of national sovereignty, but in the case of transnational law, which also operates outside the state, this legitimacy is lacking. In order to solve this problem, adherents of transnational law propose the understanding of legitimacy as based on the functional aspect of law, i.e. based on the beneficial results brought by it. ${ }^{161}$ Other authors speak about "liquid authority" in transnational governance and propose to develop more contextually variable models that are sensitive to empirical analyzes of authorities' distinctive structural characteristics. ${ }^{162}$

\section{Conclusions}

In this paper, we have in no way intended to describe exhaustively the phenomenon of transnational law or given the multitude of doctrinal approaches and lack of consensus, as well as the dynamic evolution of adjacent concepts, we consider this mission impossible. Our attempt is more modest by far. We sought to

\footnotetext{
${ }^{157}$ Affolder, Natasha. "Transnational Law as Unseen Law.” In The Many Lives of Transnational Law: Critical Engagements with Jessup's Bold Proposal. Cambridge: Cambridge University Press, 2020, pp. 365-366.

${ }^{158}$ Warning, M. J. Transnational Public Governance, p. 54.

${ }^{159}$ Hart, H.L.A. The Concept of Law. Oxford: Oxford University Press, 1961, p. 1.

${ }^{160}$ Michaels, Ralf, and Nils Jansen. "Private law beyond the state? Europeanization, globalization, privatization." The American Journal of Comparative Law 54, no. 4 (2006), p. 880.

161 See: Kanetake, Machiko. "Transnational standards in the domestic legal order: authority and legitimacy.” Transnational Legal Theory 8, no. 2 (2017), pp. 177-180.

162 Macdonald, Kate, and Terry Macdonald. "Liquid authority and political legitimacy in transnational governance." International Theory 9, no. 2 (2017), pp. 329-330.
} 
bring together in an organized way the scattered conceptions from different doctrines, legal cultures and temporal contexts, and following their analysis we can draw the following conclusions.

Transnational law has secured its place in legal thinking and today is a burgeoning phenomenon. In the classic international/national division, many gaps remain unregulated, here is therefore a space for transnational law.

Transnational law describes an area of law that regulates cross-border relations, be they commercial, political or societal, challenging the binary manner of legal thinking - international/ national, public/private, state/non-state law. Unlike international and national law, transnational law does not have a hierarchical structure, but a "polycentric" one, with multiple sources.

The transnational approach implies the acceptance of the premise the law has new sources of legitimacy. As we may have noticed, this involves a new relationship between law and the state - in which some sources of law now exist entirely outside state authority.

In all the approaches of transnational law presented in the article, one can notice as a distinct feature the denial of the state monopoly in norm-creation or, at least, the decrease of its importance. Although the evolution of new forms of regulation does not in any way mean the end of sovereignty, and nation states will continue to be the main actors for a long time to come, it would be totally wrong not to draw attention to the phenomenon of law outside the state.

Accepting legal pluralism as an alternative to the Westphalian model paradigm allows us to advance in the awareness of the transnational legal phenomenon and to focus on society, as a foundation of legal regulations.

Transnational law also redefines the spatial dimension of law, or transnational space must be understood as a metaphorical, ideational, not territorial field.

Transnational law is a key concept for emerging global governance, which in turn includes not only the actions of states and international institutions, but also the actions of non-governmental organizations and other actors of a global society.

Reappraisal of law by accepting its creation outside the state inevitably leads to the question of whether transnational law constitutes a new regime of substantive law, existing alongside state law. From a pluralistic perspective, it is undeniable the existence of the normative field of transnational law, which acts in a social space distinct from national or international law.

By accepting the above assertions, it becomes much easier to accept the autonomy of transnational law and to answer affirmative to the question in title of whether transnational law can be seen as a system of law. Let us remember that international law was also denied the quality of being a system of law no later than 60-70 years ago, being considered underdeveloped, with few courts and insignificant jurisprudence. Therefore, there is hope that in the near future transnational law will be mostly recognized as a system of law. 


\section{Bibliography}

1. Affolder, Natasha. "Transnational Law as Unseen Law." In The Many Lives of Transnational Law: Critical Engagements with Jessup's Bold Proposal, pp. 364-385. Cambridge: Cambridge University Press, 2020.

2. Aleinikoff, T Alexander. "Transnational Spaces: Norms and Legitimacy". The Yale Journal of International Law 33, no. 6 (2008): 479-90.

3. Arjona, César, et al. "What law for transnational legal education? A cooperative view of an introductory course to transnational law and governance." Transnational Legal Theory 6, no. 2 (2015): 253-286.

4. Augsberg, Ino. "Observing (the) Law: The 'Epistemological Turn' in Public Law and the Evolution of Global Administrative Law." In Regulatory Hybridization in the Transnational Sphere, pp. 9-27. Brill Nijhoff, 2013.

5. Avbelj, Matej. "The concept and conceptions of transnational and global law." $W Z B$ Berlin Social Science Centre Discussion Paper SP IV 801 (2016).

6. Avbelj, Matej. "Transnational law between modernity and post-modernity." Transnational Legal Theory 7, no. 3 (2016): 406-428.

7. Backer, Larry Catá. "Reifying Law-Government, Law and the Rule of Law in Governance Systems.” Penn State International Law Review 26 (2007): 521-563.

8. Backer, Larry Catá. "The Foundations of an Emerging Field". Last modified March 09, 2007. https://lcbackerblog.blogspot.com/2007/03/principles-of-transnational-law.html

9. Baltag, Dumitru, and Ecaterina Baltaga. "Pluralismul punctelor de vedere în problema definirii dreptului în gîndirea juridică europeană." ["The pluralism of points of view in the problem of defining law in European legal thinking"] Legea şi Viaţa 287, no. 11 (2015): 4-9.

10. Baltag, Dumitru. Teoria generală a dreptului [General theory of law]. Chișinău, 2013.

11. Berman, Paul Schiff. "From Legal Pluralism to Global Legal Pluralism." In Law, Society and Community. Socio-Legal Essays in Honour of Roger Cotterrell, pp. 255-271. Routledge, 2014.

12. Bevir, Mark. Governance: A very short introduction. Oxford: Oxford University Press, 2012.

13. Bolintineanu, A., A. Năstase, and B. Aurescu. Drept internațional contemporan [Contemporary international law], ediția a 2-a. București: ALL Beck, 2000.

14. Burley, Anne-Marie Slaughter. "International law and international relations theory: a dual agenda." The American Journal of International Law 87 (1993): 205-239.

15. Cafaggi, Fabrizio. "The architecture of transnational private regulation." EUI Department of Law Working Papers 2011/12 (2011).

16. Calliess, Gralf-Peter. "Reflexive transnational law: The privatisation of civil law and the civilisation of private law." Zeitschrift für Rechtssoziologie 23 (2002): 185-216.

17. Calotă, Adela Teodorescu. "Concepte de drept contemporan (I): globalizare, transnaţionalism juridic, europenizare, pluralism juridic.” [“Concepts of contemporary law (I): globalization, legal transnationalism, Europeanization, legal pluralism”] Revista de Științe Juridice 34, no. 1 (2019): 159-176.

18. Capuzzo, Giacomo. "Legal Expertise: On Some Uses of Law in Transnational Regimes." Comparative Law Review 4, no. 2 (2013): 1-19.

19. Carter, James H. "Transnational Law: What Is It - How Does It Differ from International Law and Comparative Law." Penn State International Law Review 23, no. 4 (2004): 797-800. 
20. Constantin, Valentin. Drept internațional [International law]. București: Universul Juridic, 2010.

21. Cotterrell, Roger. "What is transnational law?" Law \& Social Inquiry 37, no. 2 (2012): 500-524.

22. Cutler, Claire. "Legal Pluralism as the 'Common Sense' of Transnational Capitalism." Oñati Socio-Legal Series 3, no. 4 (2013): 719-740.

23. de Sousa Santos, Boaventura. "Law: a map of misreading. Toward a postmodern conception of law." Journal of Law and Society 14, no. 3 (1987): 279-302.

24. della Cananea, Giacinto. "Transnational public law in Europe." In Transnational Law - Rethinking European Law and Legal Thinking, pp. 321-345. Cambridge University Press. 2014.

25. Dickson, Julie. "Who's afraid of transnational legal theory? Dangers and desiderata." Transnational Legal Theory 6, no. 3-4 (2015): 565-585.

26. Fahey, Elaine. "Introduction: Framing the Actors of Post-National Rule-Making." In The Actors of Postnational Rule-Making: Contemporary Challenges of European and International Law, pp. 1-24. Routledge, 2015.

27. Fenwick, C. G. "Transnational Law. By Philip C. Jessup. New Haven: Yale University Press, 1956. pp. 113. \$3.00.” American Journal of International Law 51, no. 2 (1957): 444-445.

28. Garcia, Frank J. “Globalization's Law: Transnational, Global or Both?” In The Global Community Yearbook of International Law and Jurisprudence 2015, pp. 31-46. Oxford: Oxford University Press, 2016.

29. Glenn, H. Patrick. "Transnational Common Laws." Fordham International Law Journal 29, no. 3 (2005): 457-471.

30. Green, Jessica F. "Transnational delegation in global environmental governance: When do non-state actors govern?" Regulation \& Governance 12, no. 2 (2018): 263-276.

31. Griffiths, John. "What is legal pluralism?" The Journal of Legal Pluralism and Unofficial Law 18, no. 24 (1986): 1-55.

32. Hart, Herbert Lionel Adolphus. The Concept of Law. Oxford: Oxford University Press, 1961.

33. Huntington, Samuel P. "Transnational Organizations in World Politics." World Politics: A Quarterly Journal of International Relations 25, no. 3 (1973): 334-368.

34. Hyde, James N. “Transnational law.” The Yale Law Journal 66 (1957): 813-816.

35. Irish, Maureen. "Transnational Law and Legal Education." Windsor Yearbook of Access to Justice 31, no. 1 (2013): 215-217.

36. Isiksel, Turkuler. "Global legal pluralism as fact and norm." Global Constitutionalism 2, no. 2 (2013): 160-195.

37. Jessup, Philip C. “The Present State of Transnational Law." In The Present State of International Law and Other Essays, pp. 339-344. Springer, Dordrecht, 1973.

38. Jessup, Philip C. Transnational Law. New Haven: Yale University Press, 1956.

39. Kanetake, Machiko. "Transnational standards in the domestic legal order: authority and legitimacy." Transnational Legal Theory 8, no. 2 (2017): 177-180.

40. Kjaer, Poul F. "The concept of the political in the concept of transnational constitutionalism: A sociological perspective." In After Globalization: New Patterns of Conflict and their Sociological and Legal Reconstruction, pp. 285-321. Oslo: Arena, 2011.

41. Kjaer, Poul F. "The metamorphosis of the functional synthesis: a continental European perspective on governance, law, and the political in the transnational space." Wisconsin Law Review 2010, no. 2 (2010): 489-533. 
42. Kleinhans, Martha-Marie, and Roderick A. Macdonald. "What is a critical legal pluralism?" Canadian Journal of Law and Society 12, no. 2 (1997): 25-46.

43. Koehn, Peter H., and James N. Rosenau. "Transnational competence in an emergent epoch.” International Studies Perspectives 3, no. 2 (2002): 105-127.

44. Koh, Harold Hongju. "Trasnational Legal Process." Nebraska Law Review 75 (1996): 181-208.

45. Kratochwil, Friedrich. "Leaving Sovereignty Behind? An Inquiry into the Politics of Post-modernity." Legality and Legitimacy in Global Affairs, 127-148. Oxford: Oxford University Press, 2012.

46. Ladeur, Karl-Heinz. "Towards a Legal Theory of Supranationality — The Viability of the Network Concept.” European Law Journal 3, no. 1 (1997): 33-54.

47. Liste, Philip. "Transnational Law". Last modified February 27, 2019. http://oxfordbibliographiesonline.com/ view/document/obo-9780199743292/obo9780199743292-0251.xml.

48. Macdonald, Kate, and Terry Macdonald. "Liquid authority and political legitimacy in transnational governance.” International Theory 9, no. 2 (2017): 329-351.

49. Mann, F.A. "Transnational Law by Philip C. Jessup." The Modern Law Review 20, no. 6 (1957): 678-679.

50. Mann, Itamar. "Dialectic of Transnationalism: Unauthorized Migration and Human Rights, 1993-2013.” Harvard International Law Journal 54, no. 2 (2013): 315-391.

51. Manual of Public International Law. Edited by Max Sorensen. London: Palgrave Macmillan, 1968.

52. Maurer, Andreas. "The Concept of Participation in the Making of Transnational Law: Legitimization and Normativity in the Transnational Sphere." In Regulatory Hybridization in the Transnational Sphere, pp. 203-222. Brill Nijhoff, 2013.

53. Maurer, Andreas. "Transnational maritime law." In The Hamburg Lectures on Maritime Affairs 2011-2013, pp. 129-146. Berlin: Springer, 2015.

54. Mazilu, Dumitru. Teoria generală a dreptului [General theory of law]. București: All Beck, 1999.

55. Menkel-Meadow, Carrie. "Why and how to study transnational law." UC Irvine Law Review 1, no. 1 (2011): 97-128.

56. Merry, Sally Engle. "Global legal pluralism and the temporality of soft law." The Journal of Legal Pluralism and Unofficial Law 46, no. 1 (2014): 108-122.

57. Merry, Sally Engle. "Legal pluralism." Law \& Society Review 22, no. 5 (1988): 869-896.

58. Michaels, Ralf, and Nils Jansen. "Private law beyond the state? Europeanization, globalization, privatization." The American Journal of Comparative Law 54, no. 4 (2006): 843-890.

59. Miga-Besteliu, Raluca. Drept internațional public [Public international law]. Vol. I. Ed. 3. București: C.H. Beck, 2014.

60. Negru, Boris, and Alina Negru. "Teritoriul și spaţialitatea juridică a statului (II)." ["Territory and legal space of the state (II)"] Administrarea Publică 94, no. 2 (2017): 43-51.

61. Prosecutor v. Tadic, Case No. IT-94-1-AR72, Decision on Defence Motion for Interlocutory Appeal on Jurisdiction (Oct. 2, 1995). http://www.icty.org/x/cases/tadic/ acdec/en/51002.htm.

62. Roberts, Simon. "Against Legal Pluralism". The Journal of Legal Pluralism and Unofficial Law 30, no. 42 (1998): 95-106. 
63. Rosenau, James N. "Governance in a new Global Order" In The global transformations reader: an introduction to the globalization debate, $2^{\text {nd }}$ edition, pp. 223-233. Cambridge: Polity Press, 2003.

64. Schill, Stephan W. "Transnational legal approaches to administrative law: conceptualizing public contracts in globalization." Rivista trimestrale di diritto pubblico 1 (2014): 1-33.

65. Scott, Craig. "'Transnational Law' as Proto-Concept: Three Conceptions". German Law Journal 10, no. 6-7 (2009): 859-76.

66. Shaffer, Gregory, and Carlos Coye. "From International Law to Jessup's Transnational Law, from Transnational Law to Transnational Legal Orders." In The Many Lives of Transnational Law, pp. 126-152. Cambridge: Cambridge University Press, 2020.

67. Siliquini-Cinelli, Luca. "Legal Positivism in a Global and Transnational Age: Introduction." In Legal Positivism in a Global and Transnational Age, pp. 1-44. Springer, 2019.

68. Somek, Alexander. "Stateless Law: Kelsen's Conception and its Limits". Oxford Journal of Legal Studies 26, no. 4 (2006): 753-774.

69. Sperling, Valerie. Altered States: The Globalization of Accountability. Cambridge: Cambridge University Press, 2009.

70. Tai, Eric Tjong Tjin. "Global law for private law.” Tilburg Law Review 17, no. 2 (2012): 200-205.

71. Tamanaha, Brian Z. "The rule of law and legal pluralism in development." Hague Journal on the Rule of Law 3, no. 1 (2011): 1-17.

72. Tamanaha, Brian Z. A Realistic Theory of Law. Cambridge: Cambridge University Press, 2017.

73. The Encyclopedia of Global Studies. Vol. 4. Mark Juergensmeyer \& Helmut K. Anheier (eds.). SAGE Publications, 2012.

74. Tourkochoriti, Ioanna. "Beyond Legal Positivism in Transnational Law." In Legal Positivism in a Global and Transnational Age, pp. 253-275. Springer, 2019.

75. Tuori, Kaarlo. "Transnational law: on legal hybrids and legal perspectivism." In Transnational Law: Rethinking European Law and Legal Thinking, pp. 11-57. Cambridge University Press, 2014.

76. UN International Law Commission. Fragmentation of international law: difficulties arising from the diversification and expansion of international law. 2006. https://legal.un.org/ilc/documentation/english/a_cn4_16 82.pdf.

77. Ungureanu, Carmen Tamara. Dreptul comerţului internaţional: contracte de comert internaţional [International trade law: international trade contracts]. București: Hamangiu, 2014.

78. Voicu, Costică. Teoria generală a dreptului [General theory of law]. București: Universul Juridic, 2008.

79. Warning, Michael J. Transnational Public Governance. Palgrave Macmillan UK, 2009.

80. Woodman, Gordon R. "Legal pluralism and the search for justice." Journal of African Law 40 (1996): 152-167.

81. Zumbansen, Peer. "Comparative, global and transnational constitutionalism: The emergence of a transnational legal-pluralist order." Global Constitutionalism 1, no. 1 (2012): 16-52.

82. Zumbansen, Peer. "Defining the space of transnational law: Legal theory, global governance, and legal pluralism." Transnational Law and Contemporary Problems 21 (2012): 305-336. 
83. Zumbansen, Peer. "Law and Legal Pluralism: Hybridity in Transnational Governance." In Regulatory Hybridization in the Transnational Sphere, pp. 49-70. Brill Nijhoff, 2013.

84. Zumbansen, Peer. "Transnational law, evolving." In Elgar Encyclopedia of Comparative Law, Second Edition, pp. 898-925. Edward Elgar Publishing, 2012.

85. Zumbansen, Peer. "Transnational legal pluralism." Transnational Legal Theory 1, no. 2 (2010): 141-189.

86. Berandze, Mihail Rolandovich. "The concept of transnational law in international law." PhD diss., Diplomatic Academy of the Ministry of Foreign Affairs of the Russian Federation, 2010.

87. Varlamova, Natalija Vladimirovna. "Problems of institutionalization of the supranational level of the exercise of public authority." Proceedings of the Institute of State and Law of the Russian Academy of Sciences 6 (2014): 8-34.

88. Kudelka, Oleg Sergeevich. "On the formation of transnational law." Student Science Issues 4, no. 32 (2019): 99-105.

89. Lukashuk, Igor Ivanovich. International law. General part: Textbook for students of law faculties and universities. Moscow: Beck, 2001.

90. Maleev, Yurij Nikolaevich. "Transnational law: to be or not to be." International law 41, no. 1 (2010): 5-25.

91. Nefedov, Boris Ivanovich. Catechism of a postgraduate student of the Department of International Law. Moscow: MGIMO, 2018.

92. Tunkin, Grigorij Ivanovich. International law theory. Moscow: Zertsalo, 2000.

93. Shumilov, Vladimir Mihajlovich. "About 'Global Law' as an emerging legal supersystem.” Moscow Journal of International Law 4 (2015): 4-17. 